\title{
Species Composition of Cockroaches, Their Potential as Mechanical Vectors of Intestinal Parasites and Associated Factors Among Households in Sekota Town, Northeast Ethiopia; A Community-based Cross-sectional Study
}

\section{Habtu Debash}

College of Medicine and Health Science,Wollo University

Megbaru Alemu ( $\square$ mgbeyney@gmail.com )

Department of Medical Laboratory Science, Bahir Dar University PO Box 79, Bahir Dar, Ethiopia.

\section{Animen Ayehu}

Department of Medical Laboratory Science

Research article

Keywords: Cockroach, Intestinal parasites, Sekota, Ethiopia

Posted Date: August 4th, 2020

DOI: https://doi.org/10.21203/rs.3.rs-51948/v1

License: (c) (i) This work is licensed under a Creative Commons Attribution 4.0 International License. Read Full License 


\section{Abstract}

Background: Cockroaches pose a significant nuisance, and public health threat due to their ability to transmit pathogenic organisms including intestinal parasites. Due to little attention given to mechanical transmission of parasitic diseases by various vectors, appropriate interventions are not implemented to date.The extent to which cockroaches may harbor parasites is poorly understood in Ethiopia, particularly in the study area. This further overwhelms the already fragile program of prevention and control of parasites.

Objectives: To assess species composition of cockroaches, their potential as mechanical vectors of intestinal parasites and associated factors among households in Sekota town, Northeast Ethiopia.

Methods: A community-based cross-sectional study was conducted in households found in Sekota town from February to April 2020. A total of 402 households were selected by a systematic random sampling technique. Possible risk factors were collected via a structured questionnaire, and 1750 cockroaches were collected using jars. Species identification of cockroaches was performed using taxonomic keys, and parasite isolation was done using formol-ether and modified modified acid-fast techniques. The data analysis was done using SPSS version 23. P-value of less than 0.05 was considered statistically significant.

Results: All cockroaches collected were identified as a species of Blattella germanica (B. germanica). Overall, $63(36.0 \%)$ of the 175 batches were found to harbor intestinal parasites, E. histolytica/dispar (14.3\%) and H. nana (8.6\%) being the predominant species. About 38 (21.7\%), and $49(28.0 \%)$ of cockroaches were found to harbor parasites on external parts and gut contents, respectively. Improper latrine utilization $(P=0.006)$, presence of domestic animals $(P=0.032)$, and presence of parasite-infected child in the household $(P=0.001)$ were significantly associated with parasite carriage of cockroaches. Moreover, houses attached via two or more sides with neighboring houses $(P=0.045)$, houses with cracks on their walls $(P=0.001)$, and households with poor solid waste disposal $(P=0.001)$ were at a significantly higher odds of cockroach infestation.

Conclusion: Human and environmental factors have favoured infestation by Blattella germanica in the study area. Therefore, households housing condition, latrine utilization, and waste management systems should be improved.

\section{Background}

Cockroaches are the most notorious insects distributed throughout the world and they are inhabiting most human made structures [1]. There are more than 4,400 species of cockroach, of which 30 species are highly synanthropic (adapted to human habitation), thriving in so many habitats and consuming virtually any organic matter [2]. Of these, Periplaneta americana (American cockroach), Blattella germanica (German cockroach) and Blattella orientalis (the Oriental cockroach) are considered the most common pests to people [3]. Majority of these species live in tropical and subtropical areas where they 
are not recognized as pests. They feed on human faeces as well as human food and they can spread pathogenic bacteria, fungi and parasites in human dwellings [4]. The potential exists therefore, for mechanical transmission through physical dislodgement, regurgitation, or fecal pellet deposition onto and/or into exposed human food [5]. They are also source of potent environmental aeroallergens which provoke allergic reactions especially in children [6].

Cockroaches have an association with human waste and are able to traffic from sewers into homes and are attracted to dark and moist-warmth environment such as toilets, bathrooms, kitchens and basements [7]. Some cockroach species are not only a domiciliary pest but also the most frequent species in sewers which colonize there, and turning in to suitable environment for reproduction and growth [8].

The infestation of cockroaches in the human dwellings is increasing year after year, mainly due to insufficient dumpsites, domestic waste accumulation, poor housing standards, over-crowding and ignorance [9]. Poor environmental sanitation is believed to encourage the spread of cockroaches and sustenance of parasitic infections. Many parsitespecies have been found to be naturally associated with cockroaches. These relationships probably represent incidental associations with the omnivorous feeding behavior of cockroaches (Brenner \& Kramer, 2019). Those parasites that are spread by cockroaches can pose serious public health problems in developing countries [10].

The mechanical transmissions of parasitic diseases by cockroaches are neglected. However, cockroaches can be potential reservoirs and possible vectors for intestinal parasites [11-13]. Moreover, epidemiological information on species composition of cockroaches, their potential as mechanical vectors of intestinal parasites and associated factors is very limited in Ethiopia. So, this study aimed to assess species composition of cockroaches, their potential as mechanical vectors of intestinal parasites and associated factors among households in Sekota town, Northeast, Ethiopia.

\section{Materials And Methods}

\section{Study design, period and area}

A community based cross-sectional study was conducted from February to April, 2020 among households of Sekota town, Northeast Ethiopia. The area is located $720 \mathrm{~km}$ far from the country's capital, Addis Ababa.It has latitude and longitude of $\left(12^{\circ} 38^{\prime} \mathrm{N} 39^{\circ} 02^{\prime} \mathrm{E}\right)$ and an elevation of 2266 meters above sea level.The town has also an average annual temperature of $29^{\circ} \mathrm{C}$, an annual average rainfall of 786 $\mathrm{mm}$ and $35 \%$ humidity. Humid and hot climate makes the area conducive for cockroaches.

\section{Sample size and sampling technique}

A stratified sampling technique was employed to allocate households to four kebeles (the smallest administrative unit in Ethiopia). Then, the allocated households in each kebele was selected via a systematic random sampling technique. A total of 402 households were included, and cockroaches were 
collected from the selected households. Insecticide sprayed houses within two weeks prior to cockroach collection were excluded for cockroach collection. During sampling, the trapped cockroaches were labeled and sorted by capture sites in households (living room, kitchen and toilet) and kebele.

\section{Data collection}

Questionnaire. A face to face interview and observation was conducted by a trained nurse with the representatives of the households using a structured and pre-tested questionnaire. The questionnaire was used to collect demographic data and risk factors for cockroach infestation such as, housing condition, environmental hygiene and other independent variables.

Collection and identification of cockroaches:The cockroaches were collected using empty jars coated with a thin film of Vaseline baited with a piece of bread soaked in water. The collection jars were put at 19:00 hr and retrieved at 7:00 hr the next morning. The trapped cockroaches were transported in jars to the Tefera Hailu Memorial hospital laboratory for identification and parasitological analyses. Then, morphological identification of the cockroach species was performed using standard taxonomic keys after they were anaesthetized and killed by exposure to ether [18]. One hundred seventy five batches of cockroaches (each batch with 10 cockroaches) were processed. External body surfaces and internal (gut) contents of the cockroaches were processed as described by Haile et a/ to isolate parasite species [17].

Isolation of parasites from cockroach body surface:After species identification, each cockroach batch was placed in a tube containing $10 \mathrm{ml}$ of normal saline. The tube was shaken vigorously for two minutes to detach parasite stages from the external body of the cockroaches. Cockroaches were removed from wash solutions using forceps and fixed in $90 \%$ alcohol. Then, the wash solutions werecentrifuged at $2000 \mathrm{rpm}$ for 5 minutes. The supernatant was discarded and the sediment was used for formol-ether concentration technique and modified acid fast staining [20].

Isolation of parasites from cockroach guts:After external body examination, the cockroaches were fixed in $90 \%$ ethanol for 5 minutes. Afterwards, cockroaches were washed in saline to remove the traces of alcohol from the body of the cockroaches and allowed to air-dry at room temperature. Then, cockroaches were put on a plate for dissection; the head was severed first, followed by trimming of the wings and legs, then the abdomen was opened using fine pointed forceps with small scissors and whole gut was removed using needles. After every dissection, instruments were decontaminated to prevent cross contamination by dipping in ethanol between dissections. The excised guts were homogenized in $5 \mathrm{ml}$ of saline solution and the homogenate was filtered through gauze and centrifuged at $2000 \mathrm{rpm}$ for 5 minutes. The supernatant was decanted and the sediment $0.5-1 \mathrm{ml}$ processed further using formol-ether concentration technique and modified acid fast staining to examine for parasites [21].

\section{Quality assurance}


The questionnaire was pre-tested, and the necessary amendements were made before data collection. Training was also given for the data collectors (laboratory technicians and nurses). The principal investigator had strictly supervised the data collection.

\section{Data analysis}

The data were entered in to Epi-data version 3.1 and analyze via SPSS version 23 statistical software. Descriptive statistics and chi-square test was performed. The strength of association between dependent and independent variables was checked via the bivariate analysis. Those variables with $P<0.25$ in the binary logistic regression were taken to multiple regression analysis to control potential confounders. Pvalue $<0.05$ was considered as statistically significant.

\section{Results}

A total of 1,750 cockroaches (175 batches) were collected indoors from three different sites (living room, kitche, and toilet) of the selected households. All the collected cockroaches were identified as a species of Blattella germanica. From the total batches of cockroaches, $63(36.0 \%)$ batches were found to harbor atleast one intestinal parasite species. Regarding cockroach collection localities, the highest number of cockroach batches collected and the highest prevalence of intestinal parasites isolated were from kebele 02 and 04 , respectively. The highest proportion (52.3\%) of intestinal parasites was isolated from cockroaches collected from the toilets (Table 1).

Table1.The prevalence of intestinal parasites isolated from populations of $B$. germanica by kebelesand collection sites in Sekota town, Northeast Ethiopia, 2020.

\begin{tabular}{|c|c|c|c|}
\hline \multicolumn{2}{|l|}{ Variables } & \multirow{2}{*}{$\begin{array}{l}\text { Cockroach batches } \\
\text { examined } \\
58\end{array}$} & \multirow{2}{*}{$\begin{array}{l}\text { Cockroach batches found to harbol } \\
\text { parasites } N(\%) \\
17(29.3 \%)\end{array}$} \\
\hline Kebele & 01 & & \\
\hline & 02 & 66 & 25 (37.9\%) \\
\hline & 03 & 22 & 7 (31.8\%) \\
\hline & 04 & 29 & $14(48.3 \%)$ \\
\hline & Total & 175 & 63 (36.0\%) \\
\hline \multirow{4}{*}{$\begin{array}{l}\text { Collection } \\
\text { site }\end{array}$} & $\begin{array}{l}\text { Living } \\
\text { room }\end{array}$ & 84 & 27 (32.1\%) \\
\hline & Kitchen & 47 & $13(27.7 \%)$ \\
\hline & Toilet & 44 & 23 (52.3\%) \\
\hline & Total & 175 & 63 (36.0\%) \\
\hline
\end{tabular}




\section{The prevalence of intestinal parasites isolated from cockroaches}

Five species of medically important parasitesspecies were isolated from cockroaches. The overall prevalence of intestinal parasite was $36 \%$. The predominant species were E. histolytica/dispar (14.3\%), Hymenolepis nana (H. nana) (8.6\%), and Giardia Iamblia (G. Iamblia) (8.0\%). Other species such as Cryptosporidium parvum (C. parvum (2.9\%), and Enterobiusvermicularis (E. vermicularis) (1.7\%) were also isolated. Of the 175 batches of cockroaches examined, 38 (21.7\%), and $49(28.0 \%)$ batches were found to harbor intestinal parasites on their external body surfaces, and in their guts, respectively (Table 2).

Table2.The prevalenceof intestinal parasites isolated from the external body surfaces and gut contents of B. germanica in Sekota town, Northeast Ethiopia,2020.

\begin{tabular}{|llll|}
\hline \multirow{2}{*}{ Parasites } & \multicolumn{3}{l|}{ Cockroach batches found to harbor parasites N (\%) } \\
\cline { 2 - 4 } & \multicolumn{1}{l}{ External body surface $\mathrm{n}(\%)$} & Gut contents & Overall $\mathrm{n}(\%)$ \\
$\mathrm{n}(\%)$ & \\
\hline E. histolytica/dispar & $16(9.1 \%)$ & $20(11.4 \%)$ & $25(14.3 \%)$ \\
\hline H. nana & $7(4.0 \%)$ & $13(7.4 \%)$ & $14(8.0 \%)$ \\
\hline E. vermicularis & $10(5.7 \%)$ & $12(6.9 \%)$ & $16(8.6 \%)$ \\
\hline C. parvum & $3(1.7 \%)$ & 0 & $3(1.7 \%)$ \\
\hline Total & $2(1.1 \%)$ & $4(2.3 \%)$ & $5(2.9 \%)$ \\
\hline
\end{tabular}

\section{The prevalence of cockroach infestation and associated factors}

The overall prevalence of cockroach infestation in the surveyed households was $67.9 \%$ (273/402). The odds of cockroach infestation in houses that were attached via two or more sides with neighboring houses was twice (AOR=2.033; $\mathrm{Cl}$ : 1.015-4.072, $\mathrm{P}=0.045)$ higher than detached houses. Houses having cracks on their wall were at $4.8(\mathrm{AOR}=4.821 ; \mathrm{Cl}$ : 2.631-8.836, $\mathrm{P}=0.001)$ times higher odds of cockroach

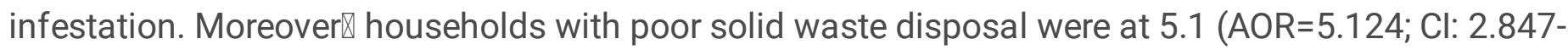
$9.222, \mathrm{P}=0.001$ ) times higher odds of being infested by roaches (Table 3 ).

Table3.Bivariate and multivariate analysis of factors associated with cockroach infestation in Sekota town, Northeast Ethiopia from February to April, 2020 ( $N=402)$. 


\begin{tabular}{|c|c|c|c|c|c|c|}
\hline \multirow[t]{2}{*}{ Variables } & & \multirow{2}{*}{$\begin{array}{l}\text { Roach- } \\
\text { infested } \\
\text { houses n } \\
(\%)\end{array}$} & \multicolumn{2}{|c|}{ Bivariable analysis } & \multicolumn{2}{|c|}{$\begin{array}{l}\text { Multivariable } \\
\text { analysis }\end{array}$} \\
\hline & & & $\begin{array}{l}\text { COR } \\
(95 \% \\
\mathrm{Cl})\end{array}$ & $\begin{array}{l}\mathrm{P}- \\
\text { value }\end{array}$ & $\begin{array}{l}\text { AOR } \\
(95 \% \\
\mathrm{Cl})\end{array}$ & $\begin{array}{l}\mathrm{P} \text { - } \\
\text { value }\end{array}$ \\
\hline \multirow{3}{*}{$\begin{array}{l}\text { House type } \\
\text { (physical } \\
\text { attachment with } \\
\text { neighboring } \\
\text { houses) }\end{array}$} & Detached & $60(14.9)$ & 1 & & & \\
\hline & Semi-detached house & $96(23.9)$ & $\begin{array}{l}2.2 \\
(1.3- \\
3.6)\end{array}$ & 0.003 & $\begin{array}{l}1.6 \\
(0.8- \\
3.4)\end{array}$ & 0.19 \\
\hline & $\begin{array}{l}\text { Attached by } 2 / \text { more } \\
\text { sides }\end{array}$ & $\begin{array}{l}117 \\
(29.1)\end{array}$ & $\begin{array}{l}2.7 \\
(1.6- \\
4.7)\end{array}$ & & $\begin{array}{l}2.3 \\
(1.1- \\
4.1)\end{array}$ & 0.045 \\
\hline \multirow{3}{*}{$\begin{array}{l}\text { Wall type of } \\
\text { houses }\end{array}$} & Concrete/brick & $41(10.2)$ & 1 & & & \\
\hline & $\begin{array}{l}\text { Stone/wood with } \\
\text { cement }\end{array}$ & $84(20.9)$ & $\begin{array}{l}2.5 \\
(1.5- \\
4.1)\end{array}$ & 0.001 & $\begin{array}{l}2.1 \\
(1.0- \\
4.5)\end{array}$ & 0.054 \\
\hline & $\begin{array}{l}\text { Stone/wood with } \\
\text { mud }\end{array}$ & )$^{148(36.8}$ & $\begin{array}{l}4.2 \\
(2.4- \\
7.4)\end{array}$ & 0.001 & $\begin{array}{l}2.5 \\
(1.3- \\
4.9)\end{array}$ & 0.080 \\
\hline \multirow[t]{2}{*}{$\begin{array}{l}\text { Cracks on the } \\
\text { wall }\end{array}$} & Present & $179(44.5)$ & $\begin{array}{l}7.5 \\
(4.6- \\
12.4)\end{array}$ & 0.001 & $\begin{array}{l}4.8 \\
(2.6- \\
8.8)\end{array}$ & 0.001 \\
\hline & Absent & $94(23.4)$ & 1 & & & \\
\hline \multirow[t]{2}{*}{ Family size } & $<5$ & $84(20.9)$ & 1 & & & \\
\hline & $\geq 5$ & $189(47.0)$ & $\begin{array}{l}1.6 \\
(1.0- \\
2.4)\end{array}$ & 0.47 & & \\
\hline \multirow{2}{*}{$\begin{array}{l}\text { Solid waste } \\
\text { disposal }\end{array}$} & Good & $82(20.4)$ & 1 & & & \\
\hline & Poor & 191(47.5) & $\begin{array}{l}6.5 \\
(4.1- \\
10.4)\end{array}$ & 0.001 & $\begin{array}{l}5.1 \\
(2.8- \\
9.2)\end{array}$ & 0.001 \\
\hline \multirow{2}{*}{$\begin{array}{l}\text { Liquid waste } \\
\text { disposal }\end{array}$} & Good & $67(16.7)$ & 1 & & & \\
\hline & Poor & $\begin{array}{l}206 \\
(51.2)\end{array}$ & $\begin{array}{l}1.6 \\
(1.0- \\
2.5)\end{array}$ & 0.046 & $\begin{array}{l}1.1 \\
(0.6- \\
2.2)\end{array}$ & 0.679 \\
\hline \multirow[t]{2}{*}{$\begin{array}{l}\text { Availability of } \\
\text { domestic } \\
\text { animals }\end{array}$} & Yes & $217(54.0)$ & $\begin{array}{l}4.2 \\
(2.7- \\
6.6)\end{array}$ & 0.021 & $\begin{array}{l}2.6 \\
(1.4- \\
4.7)\end{array}$ & 0.082 \\
\hline & No & $56(13.9)$ & 1 & & & \\
\hline Proper latrine & Yes & $89(22.1)$ & 2.9 & 0.001 & 1.7 & 0.072 \\
\hline
\end{tabular}


utilization

(1.9-

$(0.9-$

No

184(45.8)

1

Cockroach batches collected from houses with improper utilization of latrine (AOR=3.2; $\mathrm{Cl}$ : 1.411-7.381, $\mathrm{P}=0.006)$, and houses with domestic animals ( $\mathrm{AOR}=2.6$; $\mathrm{Cl}$ : $1.085-6.004, \mathrm{P}=0.032)$ were at higher odds of carrying parasites. Moreover, the presence of a child with intestinal parasite infection in the household was significantly associated with cockroach's parasite carriage (AOR=6.7; $\mathrm{Cl}$ : $2.775-12.223, \mathrm{P}=0.001)$ (Table 4).

Table4.Bivariate and multivariate analysis of factors associated with parasite carriage of cockroaches in Sekota town, Northeast Ethiopia, 2020 ( $N=175)$. 


\begin{tabular}{|c|c|c|c|c|c|c|}
\hline \multirow[t]{2}{*}{ Variables } & & \multirow{2}{*}{$\begin{array}{l}\text { Roaches } \\
\text { harboring IP } \\
\mathrm{n}(\%)\end{array}$} & \multicolumn{2}{|c|}{ Bivariable analysis } & \multicolumn{2}{|c|}{$\begin{array}{l}\text { Multivariable } \\
\text { analysis }\end{array}$} \\
\hline & & & $\begin{array}{l}\text { COR } \\
(95 \% \\
\mathrm{Cl})\end{array}$ & $\begin{array}{l}\mathrm{P}- \\
\text { value }\end{array}$ & $\begin{array}{l}\text { AOR } \\
(95 \% \\
\mathrm{Cl})\end{array}$ & $\begin{array}{l}\mathrm{P} \text { - } \\
\text { value }\end{array}$ \\
\hline \multirow[t]{3}{*}{ Type of latrine } & Flush latrine & $2(1.1)$ & 1 & & & \\
\hline & $\begin{array}{l}\text { Pit latrine } \\
\text { with slab }\end{array}$ & 16(9.1) & $\begin{array}{l}1.8 \\
(0.9- \\
3.8)\end{array}$ & 0.908 & & \\
\hline & $\begin{array}{l}\text { Pit latrine } \\
\text { without slab }\end{array}$ & $35(20)$ & $\begin{array}{l}5.3 \\
(1.1- \\
24.4)\end{array}$ & 0.305 & & \\
\hline \multirow[t]{2}{*}{ Solid waste disposal } & Good & $31(17.7)$ & 1 & & & \\
\hline & Poor & $32(18.3)$ & $\begin{array}{l}2.8 \\
(1.5- \\
5.4)\end{array}$ & 0.002 & $\begin{array}{l}2.4 \\
(1.1- \\
4.9)\end{array}$ & 0.054 \\
\hline \multirow[t]{2}{*}{ Liquid waste disposal } & Good & $13(7.4)$ & 1 & & & \\
\hline & Poor & $50(28.6)$ & $\begin{array}{l}2.2 \\
(1.1- \\
4.6)\end{array}$ & 0.030 & $\begin{array}{l}1.9 \\
(0.8- \\
4.8)\end{array}$ & 0.128 \\
\hline \multirow[t]{2}{*}{$\begin{array}{l}\text { Availability of domestic } \\
\text { animals }\end{array}$} & Yes & $46(26.3)$ & $\begin{array}{l}2.9 \\
(1.5- \\
5.7)\end{array}$ & 0.002 & $\begin{array}{l}2.6 \\
(1.1- \\
6.0)\end{array}$ & 0.032 \\
\hline & No & $17(9.7)$ & 1 & & & \\
\hline \multirow[t]{2}{*}{ Proper latrine utilization } & Yes & 15(8.6) & 1 & & & \\
\hline & No & $38(21.7)$ & $\begin{array}{l}3.8 \\
(1.9- \\
7.7)\end{array}$ & 0.001 & $\begin{array}{l}3.2 \\
(1.4- \\
7.4)\end{array}$ & 0.006 \\
\hline \multirow[t]{3}{*}{ Roach collection site } & Kitchen & $13(7.4)$ & 1 & & & \\
\hline & Living room & $23(13.1)$ & $\begin{array}{l}2.3 \\
(1.1- \\
14.9)\end{array}$ & 0.83 & & \\
\hline & Toilet & $27(15.4)$ & $\begin{array}{l}2.9 \\
(1.2- \\
16.8)\end{array}$ & 0.281 & & \\
\hline \multirow[t]{2}{*}{$\begin{array}{l}\text { Availability parasite- } \\
\text { infected child in the } \mathrm{HH}\end{array}$} & Yes & $52(29.7)$ & $\begin{array}{l}7.6 \\
(3.6- \\
16.2)\end{array}$ & 0.001 & $\begin{array}{l}6.7 \\
(2.8- \\
12.2)\end{array}$ & 0.001 \\
\hline & No & $11(6.3)$ & 1 & & & \\
\hline
\end{tabular}




\section{Discussion}

Cockroaches are nuisance pests and great concern to public health due to their ability to serve as mechanical vectors of pathogens including parasites [22]. Results from this study showed that $E$. histolytica/dispar (14.3\%) was the predominant parasite isolated from cockroaches. It was was lower than the prevalence reported by Bala \& Sule (2012) in Nigeria [23]. The predominance of E. histolytica might probably be because of the ability of the cyst to survive days to weeks in the external environment, and henceit can be accessed by cockroaches. Adenusi et al [24], and Oyeyemi et al [25] reported that the presence of E. vermicularis signifies the obvious contact of cockroaches with infected persons in houses or clothing which confirms roaches' ability to transmit different parasites that are responsible for a number of disease conditions in man, some of which could be life-threatening. For example E. histolytica causes amoebiasis, a potentially severe and life threatening disease and the second most common cause of death from parasitic diseases, after malaria. Cryptosporidium spp. and G. lamblia are also nowadays, major causes of diarrhea especially in children [17, 22]. Cryptosporidium parvum and Giardia spp. are zoonotic protozoans isolated from cockroaches. This indicates that cockroaches can serve as mechanical vectors of several zoonotic parasites which cause zoonotic disease [24].

In our study the prevalence of intestinal parasites was $28.0 \%$ in the gut, and $21.7 \% 5$ on the external body surface of cockroaches. The difference was statistically significant $(X 2=176.5, P=0.001,95 \% \mathrm{Cl}=0.001$, 0.017). It is supported by Hamu et al. (2014), that reported higher rate of parasite isolation in the cockroaches' gut ( $75.6 \%$ in the gut $\& 10.9 \%$ on external surface). This might be due to the voracious feeding habit of cockroaches that might end up with ingestion of parasites from the fecal material [19]. In contrast, a report by Edwin (2019) showed that $65.3 \%$ of total parasites obtained were isolated from the external surface, while gut contents had $34.6 \%$ [7].

In this study, overall parasite carriage rate (36.0\%) of cockroaches recorded was lower than previous studies in Ethiopia with 75.1-75.6\% (17, 19), Cameron with 47.39\% [22] and Nigeria with $96.4 \%$ [24]. However, it was higher than an earlier finding in Palestine with 17.3\% [26]. The differences in hygienic conditions, socio-economic status of the people, transmission dynamics, andprevention \& control measures taken for intestinal parasites in these various areas might account for the variation.

The highest prevalence of intestinal parasites was isolated from cockroaches collected in toilets (15.4\%), while the lowest record was in kitchens $(7.4 \%)$. The difference was statistically significant $(\chi 2=7.0, P=$ $0.029,95 \% \mathrm{Cl}=0.004,0.053)$. Alzain (2013) revealed in his study that almost all cockroaches collected from toilets were contaminated with various parasite species which were significantly higher in comparison to other sites. Ojianwuna et al also observed that the cockroaches collected from the toilets had more parasites, probably because they are easily exposed to and contaminated by fecal matter [16].

The current study identified that houses that are attached by two or more sides with neighboring houses were twice at higher odds of cockroach infestation (AOR=2.0). This finding is supported by a study done 
in Nigeria [24]. This might be due to cockroaches' tendency to congregate in corners while foraging, and traveling along the edges of walls or other surfaces. Moreover, the odds of cockroach infestation was higher for houses having cracks on their wall (AOR=4.8). This might be because of cockroaches would love to hide in dark, and warm areas especially narrow spaces. Furthermore, our study indicates that households with poor solid waste disposal were at 5 times higher odds of cockroach infestation than those having good waste disposal systems. Poor environmental sanitation is believed to encourage the spread of cockroaches and sustenance of parasitic infections [10].

In this study, different factors were found to be significant predictors of parasite carriage by the cockroaches. Consequently, cockroaches present in households the owned domestic animals were at 2.6 times higher odds of parasite carriage. This is supported by a study done in Cameron [22]. This might be due to the zoonotic nature of some parasites, and animals can also carry parasites on their body from the outdoors bring them to the indoors for easy access by cockroaches. Moreover, cockroach batches collected from households with improper utilization of latrine were at 3.2 times higher odds of harboring parasites. In the same way, the presence of parasite infected child in the household puts cockroaches at higher odds of parasite carriage (AOR= 6.7). This might be partially explained by the fact that the improper human excreta disposal might end up with piles of faecal matter that can attract cockroaches $[19,25]$.

\section{Conclusion}

Blattella germanica was found to be the only cockroach species in the study area. A significant number of cockroaches also harbored intestinal parasites. Various human and environmental factors have favoured cockroach infestation in the area..Therefore, it is imperative to institute control measures like improving housing condition, utilization of latrine, proper domestic waste management and environmental sanitation in order to minimize cockroach infestation.

\section{Declarations}

\section{Ethics approval and consent to participate}

Ethical approval was obtained from the Ethical review board of College of Medicine and Health Sciences, Bahir Dar University. After the purpose of the study explained to the selected households, informed written consent was obtained from each study participant. All information obtained at each course of the study was kept confidential. The findings of the study was communicated and oriented for their better management of their house and environment to avoid the cockroaches.

\section{Consent for publication}

Consent for publication is not applicable as individual data such as images and videos did not accompany this manuscript. 


\section{Availability of data and materials}

Data were collected and analyzed based on the stated methods and materials to generate findings of this study. All the data were incorporated into the manuscript and no supplementary files accompanied the submission. The original data supporting this finding will be available at any time upon request.

\section{Competing interests}

Authors declared they have no conflicting interest.

\section{Funding}

The research project was not funded by any organization.

\section{Authors' contributions}

Considerable contributions were made by all authors during the conception, design, and acquisition of data, analysis, and interpretation of data to this study. They have drafted and approved the final version of the manuscript and declared to bear the responsibility of all aspects of the research work.

\section{Acknowledgment}

We are thankful to laboratory personnel for their devotion to species identification of cockroaches and parasite isolation. We also thank the households for their participation.

\section{References}

1. Nasirian, H. Infestation of cockroaches (Insecta: Blattaria) in the human dwelling environments. Acta Tropica ,2017;167: 86-98.

2. Beccaloni, G. Cockroach species file online, 2014. Available at http://cockroach species file.org/homepage (Accessed: $1^{\text {st }}$ November 2019).

3. Salehzadeh, A., Tavacol, P., \& Mahjub, H. Bacterial, fungal and parasitic contamination of cockroaches in public hospitals of Hamadan, Iran. Journal of Vector Borne Diseases, 2007; 44(2): 105.

4. Isaac, C., Orue, P., lyamu, M., Ehiaghe, J., \& Isaac, O. Comparative analysis of pathogenic organisms in cockroaches from different community settings in Edo State, Nigeria. The Korean Journal of Parasitology, 2014; 52(2): 177. 
5. Graczyk, T., Knight, R., \& Tamang, L. Mechanical transmission of human protozoan parasites by insects. Clinical Microbiology, 2005;18(1): 128-132.

6. Rabito, F., Carlson, J., He, H., Werthmann, D., \& Schal, C. A single intervention for cockroach control reduces cockroach exposure and asthma morbidity in children. Journal of Allergy and Clinical Immunology, 2017;140(2): 565-570.

7. Edwin, I. Spatial Distribution and Prevalence of Parasites Vectored by Periplaneta americana in Southern, Nigeria. Asian Journal of Biological Sciences, 2019;12(2): 313-319.

8. Nasirian, H., \& Salehzadeh, A. Control of cockroaches (Blattaria) in sewers: A practical approach systematic review. Journal of Medical Entomology, 2018; 56(1): 181-191.

9. Pan, X., \& Zhang, F. Advances in biological control of the German cockroach Journal of Biological Control, 2019; 44(11): 1-51.

10. Ngwawe, C. Assessment of cockroach infestation levels, awareness and control practices of vendors in ready-to-eat food premises in Kisumu city,Kisumu county. American Journal of Humanities and Social Sciences Research, 2017; 13(3): 63-76.

11. Brenner, R., \& Kramer, R. Cockroaches (Blattaria). Medical and Veterinary Entomology, 2019; 28: 61-77.

12. Freeman, M., Strunz, E., Utzinger, J., \& Addiss, D. Interventions to improve water, sanitation, and hygiene for preventing soil-transmitted helminth infection. Jornal of Cochrane, 2016; 5(1): 1.

13. Yaro, C. Evaluation of the role of cockroaches as carriers of medically important parasites in two distinct communities in Zaria, Nigeria. Journal of Global Science Research, 2015; 2(2): 114-119.

14. Dingha, B., O'Neal, J., Appel, A. \& Jackai, L. Integrated pest management of the German cockroach (Blattodea: Blattellidae) in manufactured homes in rural North Carolina. Florida Entomology, 2016;99(4): 587-593.

15. Okpara, E., \& Amos, N. Literature review oncockroach-borne human parasites of public health concern. Journal of Entomology and Zoology, 2019; 7(3): 1507-1510.

16. Ojianwuna, C. Potentials of cockroach vectors in transmitting parasites of medical importance in Abraka, Delta State Nigeria. International Journal of Applied Biological Research, 2014; 6(2), 9-20.

17. Haile, T., Mariam, A., Kiros, S., \& Teffera, Z. Cockroaches as carriers of human gastrointestinal parasites in Wolkite Town, southwestern Ethiopia. Journal of Parasitology and Vector Biology, 2018;10(2): 33-38.

18. Choate, P., Burns, S., Olsen, L., Richman, D., Perez, O., Patnaude, M., et al. A Dichotomous key for the identification of the cockroach fauna (Insecta: Blattaria) of Florida. Florida Entomology, 2008;72: 612- 
617.

19. Hamu, H., Debalke, S., Zemene, E., Birlie, B., Mekonnen, Z., \& Yewhalaw, D. Isolation of intestinal parasites of public health importance from cockroaches in Jimma Town, Southwestern Ethiopia. Journal of Parasitology Research, 2014; 1(1): 1-5.

20. Cheesbrough, M. District laboratory practice in tropical countries. Cambridge University Press, 2006; 18(1): 126-132.

21. Okafor, E., \& Elenwo, A. Human infecting parasitic worms, in cockroaches from Odau, Nigeria. Journal of Natural Science Research, 2014;2(10): 176-184.

22. Atiokeng Tatang, R., Tsila, H., \& Wabo Poné, J. Medically important parasites carried by cockroaches in Melong subdivision, littoral, Cameroon. Journal of Parasitology Research, 2017;20(1): 8.

23. Bala, A., \& Sule, H. Vectorial potential of cockroaches in transmitting parasites of medical importance in Arkilla, Sokoto, Nigeria. Nigerian Journal of Basic and Applied Sciences, 2012; 20(2): 111-115.

24. Adenusi, A., Akinyemi, M., \& Akinsanya, D. Domiciliary cockroaches as carriers of human intestinal parasites in Lagos Metropolis, Southwest Nigeria. Journal of Arthropod-Borne Diseases, 2018; 12(2): 141.

25. Oyeyemi, O., Agbaje, M., \& Okelue, U. Food-borne human parasitic pathogens associated with household cockroaches and houseflies in Nigeria. Parasite Epidemiology and Control, 2016; 1(1): 10-13.

26. Alzain, B. Transmission of medically important parasites bycockroaches. Journal of Science and Technology, 2013; 90(28): 31. 